\title{
MARKETING ALBERTA NATURAL GAS: A PRODUCER'S PERSPECTIVE FOLLOWING DEREGULATION
}

\author{
PHILIP H. DAVIES*
}

\begin{abstract}
Numerous changes in the statutory and regulatory framework governing the marketing of natural gas have affected the manner in which the petroleum industry negotiates the purchase, sale and transportation of natural gas. This paper reviews provisions contained in gas purchase contracts and offers a producer's perspective on gas purchase contracts, gas transmission services and regulatory approvals.
\end{abstract}

\section{INTRODUCTION}

Change in the statutory and regulatory framework governing the marketing of Alberta natural gas in Canada has challenged the producing industry to re-examine the manner in which it conducts its business. Issues, previously addressed by regulation, must now be negotiated.

Taking a producer's perspective of gas purchase agreements, gas transportation services and regulatory approvals, this paper offers practical advice which may assist counsel. Particular emphasis is placed on analyzing the provisions of long-term gas purchase contracts which relate to pricing, buyer's take obligations and seller's supply commitment. Numerous examples are drawn from contracts presently circulating within the industry.

\section{BACKGROUND}

The present regulatory regime had its beginning in the Western Accord of March, 1985, an agreement amongst the federal government and the governments of the three western provinces. The political impetus for change grew out of the Mulroney Government's campaign commitment to the West to right the perceived wrongs which accumulated during the Trudeau era to the detriment of the oil and gas industry. Market factors and U.S. regulatory developments further accelerated the move toward change in Canada.

The Western Accord achieved a number of goals long sought by the oil and gas industry, including:

1. deregulation of crude oil pricing and marketing;

2. fiscal reform including elimination of the PGRT, the Petroleum Compensation Charge and the Canadian Ownership Special Charge; and

3. recognition of the need to move to a flexible market-oriented pricing mechanism for domestic natural gas.

Prior to discussing the various changes initiated by the Western Accord, it is useful to recall the circumstances in which the Accord was reached. Insofar as the natural gas industry in Canada was concerned, those circumstances included the following significant features:

1. Pricing:

- Alberta Border Price regulated,

- Toronto City Gate price regulated,

- Export Price regulated, and

- intra-Alberta price to industrial consumers purchasing directly, largely unregulated. 
2. Transportation:

- constrained access to transportation service on distribution systems,

- transportation service available on TCPL, and

- transportation service on distributors' systems outside of Alberta either restricted or non-existent.

3. Market Access:

- ERCB surplus test for removal permit used $25 \mathrm{~A}_{1}$ test, i.e. applicant was required to show that surplus gas was available for 25 years of current Alberta demand, ${ }^{1}$ and

- direct sales not common, except intra-Alberta direct sales to industrial consumers.

\section{Other:}

- dominance of "system" gas in most Canadian markets east of Alberta.

The goal of many producers in promoting deregulation was to permit the normal market forces to function in natural gas markets as unimpeded as possible, given all the circumstances at hand. This goal was to be implemented with the following changes: ${ }^{2}$

- market responsive pricing by the parties to the contract - not government imposed pricing,

- open transportation access from the wellhead to the burner tip,

- greater access by producers to domestic and export markets,

- greater access by consumers to competing supplies of natural gas, and

- generally less government control within the natural gas market place.

All of which, it was argued, was to be implemented while preserving the sanctity of existing contracts.

Much has been written since dealing with the specific steps taken in restructuring the legislative and regulatory regime governing the industry. Other authors ${ }^{3}$ have examined the new laws enacted by legislators and the new decisions issued by regulators. The purpose of this paper is to build on the foundation laid by those others and identify the ramifications which impact upon producers as a result of those changes in their industry.

In this paper, after briefly listing the steps in two typical direct sales, we will focus on three major areas. First, we will discuss the gas purchase contract, looking specifically at three topics: the provisions found therein which relate to pricing, seller's obligation to deliver (security of supply) and buyer's obligation to nominate and take delivery (security of market). Secondly, we will list the various classes of gas transportation service available on the NOVA system and TransCanada PipeLines Limited ("TCPL") and point out those circumstances in which each class will apply. Some discussion will ensue as to the anticipated changes which may be

1. Energy Resources Conservation Board, “Report No. 79-I: Alberta's Gas Supply Protection Procedures and Formulae" December 1979.

2. See e.g. Independent Petroleum Association of Canada and Canadian Petroleum Association, "Energy Options - Natural Gas Showcase, Producer's Perspective" (7 December 1987).

3. See e.g. A.L. McLarty and D.A. Holgate, "Natural Gas Deregulation: Review and Perspective" (1987) XXVI Alta. L. Rev. I; D.C. Edie, "Marketing of Alberta Gas for Export Under Deregulation" (1987) XXVI Alta. L. Rev. 46; and panel presentation, "Summary Respecting the Panel Presentation on Deregulation of the Natural Gas Industry" (1986) XXV Alta. L. Rev. 1. 
coming in the NOVA and TCPL tariffs. Finally, we will examine the removal permit process and the current criteria used by the Alberta Energy Resources Conservation Board ("ERCB").

\section{TYPICAL DIRECT SALES OF ALBERTA NATURAL GAS}

In this section, we will look first to an end user located in Alberta and secondly to one located in Ontario. In each case, we will assume that the delivery point is buyer's "plant gate". Consideration of a U.S. direct sale is beyond the scope of this paper.

The following comprise the steps in a typical direct sale to an Alberta end user:

- production, processing, transportation on gathering system and delivery to NOVA receipt point,

- intra-Alberta transportation on either or both NOVA and distributor, and

- purchase and sale of gas.

A typical Ontario direct sale entails the following:

- production, processing, transportation on gathering system and delivery to NOVA receipt point,

- intra-Alberta transportation to the Alberta border (Empress),

- Alberta removal permit,

- TCPL transportation service,

- transportation service on Ontario distribution system, and

- purchase and sale of gas.

\section{THE GAS PURCHASE CONTRACT}

\section{A. GENERAL}

This section of the paper will examine, from a producer's perspective, the contractual responses which parties to long-term gas purchase contracts have developed to address various issues arising from deregulation.

A gas purchase contract will address a number of matters, which typically include the following:

- definitions, including units of time, units of volume, units of energy and description of seller's interest in gas reserves to be produced,

- description of contract quantities, such as minimum annual obligation, daily contract quantity and maximum daily volume,

- commencement of deliveries,

- point of delivery,

- delivery pressure,

- quality specifications,

- measurement,

- term of contract,

- price,

- billings and payments,

- transfer of possession / warranty of title,

- force majeure, 
- arbitration, and

- "boiler plate".

We will focus on those of the above provisions which pertain to three subject matters, namely:

- pricing,

- provisions assuring seller of market security, and

- provisions assuring buyer of supply security.

\section{B. PRICING}

\section{Statutory Context}

Parties to gas purchase contracts negotiated prior to deregulation could, and often did, largely ignore the issue of pricing. It was a matter of governmental policy. Typically, the parties either adopted the regulated pricing provisions or they agreed to a price determined by reference thereto. Examples exist of contracts which do not provide for a means of determining price should the regulated price cease to exist. Indeed the Government of Alberta, when drafting the Natural Gas Marketing Act, ${ }^{4}$ anticipated that with the removal of the Alberta Border Price some contracts, containing no independent pricing provisions, could be void for uncertainty. Section 12 was therefore added to the Act to ensure that a party to a contract governed by Alberta law, where the price of gas was not ascertainable by reason of the termination of gas pricing regulations, could direct that the price be re-determined by arbitration under the Arbitration Act of Alberta. ${ }^{5}$

Moving to market determined prices has required a considerable re-orientation of the producing and consuming industry. All the major gas buyers were involved in protracted negotiations with their producers. Many adopted the concept of a market determined price "netted back" to the producer. Part 2 of the Natural Gas Marketing Act provides the statutory framework for netback pricing. Section 8 (c) reads as follows:

8 (c) "Netback Pricing Formula" means a formula or method under which the actual price payable by the shipper for marketable gas sold and delivered pursuant to a producer-shipper contract is calculated wholly or partly by reference to a price or prices payable to the shipper on the resale of the gas by him, whether the formula or method is contained in or incorporated by reference in the producer-shipper contract;

Section 9 of the Natural Gas Marketing Act prohibits a shipper from removing netback gas from Alberta for resale outside Alberta and from delivering such gas in Alberta for resale to another person, unless there is a prior finding of producer support in relation to such netback gas. The Alberta Petroleum Marketing Commission ("APMC") is charged with responsibility to issue a finding of producer support for any sale of netback gas meeting the criteria set forth in section 9 of the Natural Gas Marketing Act. The minimum producer support required is set out in Part 2 of the Regulation ${ }^{6}$ enacted pursuant to section 11 of the Natural Gas Marketing Act. Section 10 (1) of that Regulation reads as follows:

4. Natural Gas Marketing Act, S.A. 1986, c. N-2.8, as am.

5. Arbitration Act, R.S.A. 1980 c. A-43, as am.

6. Natural Gas Marketing Regulations, Alta. Reg. 358/86, as am. 
10. (1) The Commission shall make a finding of producer support if

(a) the matter in respect of which the prescribed minimum degree of support of the producers is required under section 9 (2) (a) or (b) of the Act is in the form of a question to be submitted to those producers for a vote.

(b) the Commission determines that the vote on the question has been conducted in accordance with section 11 , and

(c) the Commission determines,

(i) at least $51 \%$ of the producers entitled to vote on the question have voted, or are deemed under section 11 to have voted, in favour of the question, and

(ii) the producers or the principal sellers, as the case may be, having at least $70 \%$ of the percentage interests in the aggregate of the attributed contract quantities for all producershipper contracts under which the shipper buys netback gas have voted. or are deemed under section 11 to have voted. in favour of the question.

Section 11 of that Regulation provides that a producer's failure to respond when required to vote shall be deemed to be a response in the affirmative.

The Alberta Petroleum Marketing Commission recently solicited comments on the appropriateness of the present form of producer endorsement mechanism. By letter dated April 12,1988, the Commission advised interested parties that, in spite of receiving a broad range of suggested changes, it would recommend to the Alberta Government that it leave the provisions as they presently stand.

In a specific direct sale, of course, the producer endorsement mechanism is not applicable. It is mentioned to illustrate the statutory restructuring of pricing provisions found in certain gas sales contracts. One other important statutory change is the amendment to the Arbitration Act of Alberta, section 17 of which now reads:

17. (1) In this section,

(a) "arbitrator" includes an umpire and referee in the nature of an arbitrator;

(b) "end user" means the buyer of gas under a gas contract who purchases the gas for the purpose of using or consuming it:

(c) "gas" means a gaseous mixture consisting primarily of methane;

(d) "gas contract" means a contract under which gas is sold and delivered by a seller to a buyer, and includes an agreement that varies or amends that contract and an arbitration award that relates to that contract.

(2) Subject to subsection (3), this section applies to every submission, whether coming into existence before or after the coming into force of this section, that provides for the arbitration of present or future differences relating to:

(a) the initial determination or a redetermination of the price of gas delivered under a gas contract,

(b) the creation, replacement or modification of a method or formula for the calculation of the price of gas delivered under a gas contract, or

(c) the determination of the price of gas delivered under a gas contract in place of a method or formula for the calculation of the price of gas delivered under the gas contract.

(3) The buyer and seller under a gas contract may agree to vary or make inapplicable all or any of the provisions of this section in relation to a submission to which this section applies only if the agreement is made after the coming into force of this section.

(4) In an arbitration under this section the arbitrator shall have regard to at least the following matters to the extent that evidence is adduced with respect to those matters:

(a) the prices of substitutable energy sources

(i) that compete with gas for the various end uses of gas in the markets served by the buyer, where the buyer is not the end user of the gas, or

(ii) that are available for use or consumption by the buyer in place of gas, where the buyer is the end user of the gas,

taking into account any differences in the efficiencies of gas and those substitutable energy sources:

(b) the prices of other gas 
(i) that competes in the same markets as those being served by the buyer, where the buyer is not the end user of the gas, or

(ii) that is available for use or consumption by the buyer, where the buyer is the end user of the gas;

(c) the explicit or implicit prices of other gas produced in Alberta and delivered under other gas contracts;

(d) the prices for gas in markets outside Canada that could be served by gas produced in Alberta if there were no quantitative restrictions imposed on the export of gas from Canada by or under any law in force in Canada.

(5) The arbitrator, in having regard to each of the matters enumerated in subsection (4), shall take at least the following matters into account to the extent that evidence is adduced with respect to those matters:

(a) differences in transportation costs;

(b) the times at which prices were agreed to between the respective sellers and buyers;

(c) similarities and dissimilarities between the provisions of the gas contract and the provisions of contracts for the purchase of the substitutable energy sources and gas referred to in subsection (4)

(6) In an arbitration under this section,

(a) the arbitrator must be ordinarily resident in Alberta, if the arbitration is conducted by a single arbitrator, and

(b) at least half of the arbitrators must be ordinarily resident in Alberta, if the arbitration is conducted by 2 or more arbitrators.

The two most significant changes in the arbitration provisions effected by the above revision are, firstly, that the arbitrator is now entitled to consider competitive gas sales and, secondly, that the parties are at liberty to substitute other terms of reference than those imposed by section 17 .

Arbitration, using the above provisions, may be a clumsy tool. How are the parties to gain access to exhaustive pricing data to present to the arbitrators? Will an expert, retained by buyer or seller, be at liberty to fully disclose relevant pricing information gained in his relationship with other clients, without violating undertakings of confidentiality? What influence will the Competition $\mathrm{Act}^{7}$ have on a party's ability to collect pricing data? Will the APMC or the ERCB emerge as a repository of such information?

On a related issue, is the substantial regulatory change in respect of natural gas pricing enough to permit a party to argue that the performance of the contract is a thing radically different than what was originally undertaken by the parties? Certainly the recent decision of Mr. Justice O'Leary in Petrogas Processing Ltd. v. Westcoast Petroleum Ltd. ${ }^{8}$ decided that such was the case. More will be said of that case later in this paper.

\section{Contractual Provisions - Pricing}

On a contractually specific basis, producers have been challenged to rethink entirely the manner in which they structure the pricing provisions of their gas sales contracts. What had previously been handled by regulation, must now be addressed in negotiation.

Whether we look to an intra-Alberta direct sale or one taking place in Ontario, the parties to the contract must deal with the difficulty of designing pricing terms which mesh with their pricing projections.

7. Competition Act, S.C. 1986, c. C-23, as am.

8. Petrogas Processing Lid. v. Westcoast Transmission Co. [1988] W.W.R. 699, 59 Alta. L.R. (2d) 118. 
This section of the paper will examine some of the various pricing provisions which have been agreed to by parties to long-term gas purchase contracts. Those provisions may be grouped into three general categories, namely:

-Lump-Sum Contracts in which the purchase price is fully or substantially prepaid,

- Fixed Unit Price Contracts with or without periodic review, and

- Variable Price Contracts in which all or a part of the price is determined by a formula, quantifying data relevant to the circumstances of the parties.

Let us look in more detail at each of the above.

\section{(a) Lump Sum Contracts}

Crossborder Report ${ }^{9}$ recently carried an article describing an application by a U.S. company, Gas Alternative Systems, Inc., to the Economic Regulatory Agency for authorization to import 120 million MMBTU's of gas to be purchased from Noranda Inc. over a 20 year term for a fixed price, lump-sum, up front payment of U.S. $\$ 70$ million. While the price of gas was fixed, buyer was required periodically to pay Noranda's production, gathering and processing costs. These costs were calculated by multiplying a base cost of U.S. $\$ 0.30 / \mathrm{MMBTU}$ by the escalation in the U.S. GNP Implicit Price Deflator. The buyer was also required to reimburse Noranda for royalties paid and for transportation costs incurred on NOVA and TCPL. The parties agreed to share the cost of any tax imposed for export from Canada and import into the U.S. The contract in question secured a supply of gas for a cogeneration facility in the State of New York. The lump-sum pricing was agreed to, to permit buyer to fix the primary component of his fuel costs, thereby facilitating project financing. The contract avoided take-or-pay, minimum take and other similar problems by providing that buyer would forfeit all quantities of natural gas not delivered at the end of the 20 year term.

Other cogeneration contracts with which the writer is familiar have attempted to provide certainty in gas costs by developing a variable price formula related to a regulated price. More will be said below about such variable pricing provisions.

\section{(b) Fixed Unit Price Contracts}

While fixed unit prices are often found in short-term gas purchase contracts, the parties to a long-term contract will not usually agree to a fixed unit price payable periodically throughout the contract term. However, many long-term contracts provide for a fixed unit price with a periodic right by either party to compel price recalculation.

Typically, such contracts provide that if a price is not agreed to within a stipulated period, either party may submit the matter to arbitration. The terms of reference for the arbitrators may be similar to those imposed by the Arbitration Act of Alberta or some variation thereof.

Under the next heading, some of the various terms of reference used in arbitration are dealt with in detail. 


\section{(c) Variable Price Contracts}

Circumstances faced by buyers and sellers of gas often require that the relative price of gas be fixed. As discussed above, one method of doing so is to prepay the gas commodity costs. Another more common alternative is to develop a pricing formula which ensures that the price of gas delivered under the contract will bear some continuing relationship to some other determinable variable.

This section of the paper will list a number of types of such price formulae and examine several interesting examples extracted from contracts presently circulating within the industry.

Formulae agreed to from time to time by parties to gas contracts may refer to some or all of the following variables:

- comparable gas sales in the same market or one arguably similar,

- sales of other energy sources which compete in the same market or one arguably similar,

- prices determined by arbitration using the terms of reference set out in section 17 of the Arbitration Act of Alberta or particular terms of reference stipulated in the contract,

- prices determined by statute or by regulation; one example being the "avoided cost" approach sometimes taken in cogeneration projects,

- prices equal to or related to the price of "system gas" delivered in buyer's market,

- the average price of gas delivered over a stipulated period at the Alberta border or at some other reference point or, alternatively, the average price of some specific sub-category of such gas, e.g. "spot" sales,

- price "bracketing" often used by a utility obliged by its regulator to nominate gas sequentially from different suppliers, having regard to the relative cost of each such source of supply,

- tiered or incentive pricing recognizing the value of load factor and/or incremental sales,

- stepped pricing providing for stipulated periodic increments over time,

- seasonal pricing recognizing the different value of winter gas over summer gas, and

- indexed pricing relating gas pricing to some relevant economic indicator, for instance, a change in the consumer price index or the annual GNP price deflator.

The above list is not by any means exhaustive, nor are the examples listed mutually exclusive. Indeed, numerous price adjustment provisions are often combined in long-term gas purchase contracts.

The most common formulae for determining gas prices make reference to the price of other gas being sold in buyer's market or have regard to the price of other fuels/ energy sources which compete with natural gas in such market. Typically, formulae which use comparable data will contain "equalizers" to ensure the comparison is fairly made. Some of those equalizers include:

- the time when the parties to the contract entered into it,

- the material circumstances which prevailed at that time,

- load factor,

- seasonable nature of deliveries, 
- proximity of the delivery point,

- apportionment of demand and commodity components, and

- "weighting" of each competing fuel to represent its respective share in the energy market under review and to adjust for the respective cost of consuming each.

In drafting pricing formulae, counsel should be careful to avoid a number of potential difficulties which may arise:

Does the formula place heavy reliance on the ability of the parties to gain access to pricing data? Will that data be and continue to be truly representative? Are concepts incorporated in the formula clearly objective or are they to any significant extent determinable only with the application of the same subjective test? A recent example with which the author is familiar (after pages of objective formulae quantifying pricing factors) imposed the following highly subjective criterion governing price redetermination: "...a price not prejudicing the marketability of gas in buyer's distribution area".

As a final cautionary note, counsel is directed to the Alberta Court of Queen's Bench decision of May 6, 1988 addressing a claim by Petrogas Processing Ltd. ("Petrogas") against Westcoast Transmission Company Ltd. ("Westcoast"). In that case Petrogas, as seller under a gas purchase contract made in 1959, was advancing against Westcoast, the buyer under the contract, a claim for a substantial amount pursuant to the take-or-pay provisions of the contract. Petrogas alleged that Westcoast failed to take certain agreed minimum annual volumes during the years 1978 to 1985 inclusive and sought to recover the price of those annual deficiencies. In total, its claim was in excess of $\$ 170$ million prior to interest.

Subsequent to contracting with Petrogas, Westcoast sold substantially all the gas purchased to a gas distribution company in the Pacific Northwest region of the United States. The contract specified an initial price for gas and adopted a schedule of agreed increments for the 20 years following. It provided for price redetermination by negotiation or arbitration. From 1975 to the end of the contract, the prices paid by Westcoast to Petrogas and those recovered by Westcoast from its U.S. repurchaser were regulated. Beginning in 1978 and continuing through 1985, Westcoast failed to take delivery of the minimum annual volume which Petrogas alleged it was obliged to take under the contract.

The principal defence raised by Westcoast was that the contract had been frustrated as a result of the introduction of regulated prices in 1975. Alternate defences to the claim were advanced, but Mr. Justice O'Leary relied on the defence of frustration in rendering his decision.

Westcoast defended on both a narrow and broader ground. On the narrow ground, it argued that the regulation of the field price of gas made performance of the contract legally impossible. On the broader ground, it argued that the imposition of regulated export and field prices made performance of the contract a thing radically different from that contemplated by the parties when making the contract.

Mr. Justice O'Leary held that Westcoast should succeed on both arguments. He stipulated on the first ground that the contract was automatically discharged by frustration the moment performance in accordance with its terms became illegal. That moment occurred on November 1, 1975 when the parties were compelled to abide by prices imposed under the Natural Gas Pricing Agreement Act. ${ }^{10}$

10. Natural Gas Pricing Agreement Act. R.S.A. 1980, c. N-4, as am. 
As for the second ground of frustration, Mr. Justice O'Leary considered the commercial setting in which the contractual obligations were assumed as well as the relevant terms of the contract. Specifically, he found that Petrogas knew that Westcoast intended to resell virtually all the gas taken under the gas purchase contract to a U.S. repurchaser, that the contract was made in an economic climate relatively free of government regulation, and that the pricing provisions of the contract reflected the views held by the parties, in 1959, of the actual and foreseeable economics of natural gas marketing. Furthermore, he found that the evidence showed that the market for natural gas in the Pacific Northwest region of the U.S. was particularly sensitive to price and that the high uniform export price for gas from Canada was a direct and primary cause of a loss of market for Canadian gas in the region, resulting in Westcoast's inability to take minimum volumes under the contract. He therefore concluded that imposition of price regulation made performance of the contract a thing radically different than what was originally undertaken by the parties. In the result, he found the contract was discharged by frustration on both the narrow and broader grounds.

Mr. Justice O'Leary found that the contract was discharged immediately upon the occurrence of the frustrating event. In dealing with Petrogas' argument of estoppel, therefore, he held that the doctrine did not apply since the contract had already been terminated by operation of law. While the decision raises a number of interesting issues, it may well be appealed and if not, may be limited to its facts.

Notwithstanding its potential difficulties, arbitration is often used to interpret a formula for determining price. Arbitration may be conducted under terms of reference similar to those set forth in section 17 of the Arbitration Act of Alberta, or under terms of reference specifically incorporated into the contract. Consumers' Gas Company Limited recently circulated draft long-term contract conditions which imposed the following arbitration provisions:

8. Arbitration...

...the guidelines to be used by the arbitrators to determine the price at the Delivery Point are as follows:

(i) the prices of substitutable energy sources that compete with natural gas for the various end uses of natural gas in the markets served by buyer, taking into account any differences in the efficiencies of natural gas and those substitutable energy sources;

(ii) the prices of other natural gas that competes in the same markets as those being served by buyer;

(iii) the explicit or implicit prices of other natural gas delivered to the Province of Ontario under other gas contracts;

(iv) the equivalent price for gas in markets east of Saskatchewan that are currently served by gas produced in Western Canada, taking into consideration any difference in costs due to iransportation, load factor, seasonality of deliveries etc.;

(v) the times at which prices were agreed to by the respective sellers and buyers of other natural gas or substitutable energy sources under contracts for the sale and purchase thereof: and

(vi) similarities and dissimilarities between the provisions of this Agreement and the provisions of contracts for the sale and purchase of other natural gas or substitutable energy sources.

In conclusion, it is evident that considerable effort is often expended by the parties to long-term gas purchase contracts to ensure that their pricing provisions show as much sensitivity as possible to the circumstances which impact upon their respective positions.

Let us now turn to a discussion of the provisions typically negotiated by sellers in long-term gas purchase contracts to ensure that the market proposed to be served remains secure. 


\section{SECURITY OF MARKET}

This section of the paper explores the contractual means used by sellers to ensure that buyer's purchase and take obligations are met. Typically those means include:

- take-or-pay obligations,

- demand charge obligations, and

- market allocation provisions.

Let us look at each of the foregoing in detail.

\section{Take-Or-Pay}

While the take-or-pay provision is not commonly found in gas purchase contracts today, most readers will not be unfamiliar with this provision. It is usually expressed as an annual minimum obligation owed by buyer to take a stipulated percentage, of an annual contract quantity. If buyer should fail to take such stipulated percentage, it is typically provided that buyer will be obliged to pay for the shortfall volumes, even though not taken. Usually the unit price to be paid is the weighted average commodity price for the contract year in question.

The contract typically allows buyer the right to draw down prepaid gas, but only after buyer first nominates and takes the minimum volume required in the current period. Often price adjustment clauses are included to correct significant swings in price between the year the shortfall arose and the year the prepaid gas is drawn down.

Finally, the typical take-or-pay provision limits in time buyer's right to draw down prepaid gas standing to his credit, although occasionally one will see provisions permitting a short extension of the term should any such volume remain to the credit of buyer.

\section{Demand Charge Obligations}

In many gas purchase contracts, buyer is obliged to continue paying demand charges related to the transportation of gas to the delivery point, irrespective of whether or not it has nominated gas for delivery on any given date. Often force majeure provisions will moderate the demand charge obligations assumed by buyer and those provisions should be read carefully in such context.

\section{Allocation}

Some contracts contain provisions whereby, rather than stipulating a minimum annual volume to be taken, buyer agrees to nominate in accordance with some allocation formula. Typical variations of allocation clauses include the following:

- market share provisions, in which buyer agrees to allocate a defined market amongst several sellers using some formula: e.g. a percentage or a pro rata share,

- streamed supply provisions, in which all sellers are assigned into respective supply categories, which categories are preferentially ranked according to some criteria. Criteria used include gas price, length of original contract term and time when contract was entered into. Buyer nominates among its various sales contracts in accordance with such ranking, and

- right of first refusal provisions in which seller is given the first opportunity to supply gas on stipulated terms and conditions. This is usually used by buyer 
to allocate incremental volumes it requires amongst its existing sellers. Some utilities allocate their peaking gas requirements on this basis.

Considerable care must be taken when drafting any allocation provisions to clearly define both the numerator and denominator used to apportion the market in question. The denominator, of course, will be the total market in question and must be defined with some precision. The numerator will be the "factor" used to apportion the market and must reflect the allocation provisions agreed to by the parties. The language used to express each concept must lend itself as easily to quantification as that chosen to express the agreement as to price.

The draftsman must also constrain the operation of force majeure to ensure those provisions encompass only events clearly intended to relieve buyer of its take obligations. It also is important that seller have complete audit rights to ensure that the allocation provisions are being fairly interpreted in the nominating practices of buyer.

\section{Consequences Should Buyer Not Meet Its Take Obligations}

Should buyer fail to fully take the volumes it has agreed to, the typical sanctions found in long-term gas purchase contracts include:

- paying take-or-pay charges, as discussed above,

- paying demand charges, including fixed transportation costs,

- paying gas reservation fees in consideration of seller's opportunity cost,

- exercising excess volumes rights permitting seller to sell to a third party gas otherwise dedicated to buyer,

- exercising pro-rating provisions, whereby buyer is required to "super-nominate" volumes under seller's contract in the next period to make up deficiencies in a given period, and

- exercising "de-contracting" provisions permitting seller to reduce its supply obligation partially or totally.

The foregoing briefly summarizes the typical provisions used by sellers to secure the market contracted to be supplied. The next section deals with the reciprocal provisions often negotiated by buyers to secure seller's obligation to supply gas in the quantities agreed to.

\section{SECURITY OF SUPPLY}

In this section, we will explore various contractual means often adopted by a buyer of gas to ensure that it will enjoy continued access to seller's gas supplies, in the volumes contracted, throughout the term of the agreement. The common methods used by buyers are firstly, the dedication of reserves and secondly, a covenant to supply.

Let us look at each in detail:

\section{Dedication Of Reserves}

The typical dedication clause will require that seller dedicate sufficient reserves to meet its delivery obligations over the term of the contract. Often the contract will permit seller to add additional reserves. It may also permit seller to withdraw reserves 
in circumstances where it can demonstrate that the remaining dedicated reserves will be sufficient to satisfy its delivery obligations over the remaining term of the contract.

Seller's obligation to deliver from dedicated reserves is usually moderated by provisions which permit seller considerable latitude as to how it elects to exploit the gas reserves in question. Also, force majeure provisions typically exclude liability in respect of reserves which unexpectedly suffer deliverability decline.

\section{Seller's Warranty}

In gas purchase contracts, where there is no dedication of reserves, there is often a representation and warranty by the seller that it has sufficient deliverable reserves at its disposal to meet its obligation to supply over the term of the gas purchase contract. Usually, seller also covenants that it will not enter into new sales contracts nor will it voluntarily extend existing sales contracts, if to do so would increase seller's total delivery obligations (on a daily or annual basis) to the extent that the delivery obligation owed buyer could not be met. Contracts of this nature are often referred to as "seller's warranty" contracts.

Consumers' Gas Ltd. recently solicited offers, from gas sellers for supplies of gas, proposing to impose the following obligations:

II. (B)...

(iii) Prior to each contract year, seller shall supply buyer with a forecast of seller's supply and sales obligations on a daily and annual basis for at least the remaining term of this contract using the following assumptions:

(a) all purchasers take delivery of their maximum annual volumes, as limited by removal permits, export licenses, and contract conditions;

(b) all purchasers extend their existing contracts where they have the right to do so;

(c) all suppliers reduce their contract volume or de-contract whenever they have the right to do so; and

(d) the supply/demand balance is done on a daily basis at maximum rates and on an annual basis using maximum annual commitments.

\section{Consequences Should Seller Not Meet Its Supply Obligations}

Seller's warranty contracts often impose obligations on seller and bestow rights on buyer should a supply shortfall occur or be forecast. In the Consumers' Gas Ltd. proposal the following provisions are found:

11. (B)...

(iv) If a future supply shortfall occurs in the forecast then:

(a) seller may not contract to sell additional volumes as long as the deficiency exists;

(b) seller shall use its best efforts to contract for additional supplies to offset the deficiency.

(v) If there is an actual delivery shortfall on a particular day:

(a) buyer may reduce its contract volumes to the level that can be delivered by seller; and

(b) seller shall reimburse buyer for TCPL demand charges for the deficient volume.

(vi) The only force majeure condition which will excuse seller from the payment for non delivery in (v) (b) above will be a major outage on the delivery pipeline(s).

It is noteworthy that seller's obligation above to contract for additional supplies to offset a forecast deficiency is not excused if seller is unable to so contract at a reasonable price. Also note that if an actual delivery shortfall occurs on merely one day, buyer proposes that it be given the right to reduce its take obligations for the balance of the term to the level to which seller is able to supply on that day. As mentioned above, the provisions quoted are only proposed terms, "hoped for" by buyer and likely did not survive in the final form of contract negotiated. 
The Gas Alternative Systems Inc. lump sum purchase contract with Noranda Inc. mentioned earlier in this paper is also worthy of mention in the context of security of supply, especially in view of the fact that the entire commodity price for gas to be delivered over the term of the agreement is prepaid. In addition to extensive force majeure provisions, the contract provides as follows:

12.1 (a) In the event that Seller defaults for any reason other than the occurrence of an event of force majeure in its obligation to deliver to Buyer at the Point of Delivery quantities of natural gas requested by Buyer in accordance with the terms and conditions of this Agreement, and provided that Buyer would have been able to accept the gas requested if delivered but for Seller's failure to deliver, Buyer shall have the right to immediately obtain Substitute Supplies and discontinue all payments due or chargeable pursuant to sections 3.2. 3.3 [3.2 and 3.3 production, gathering and processing costs]. 3.4 [royalties] or 3.5 [export and import taxes] until Seller fully resumes performance hereunder.

(b) Following its default, Seller shall promptly inform Buyer of the reasons for the default and the anticipated duration of the period of default and shall take all steps necessary to fully resume performance as soon as possible. Buyer may obtain Substitute Supplies for the period of the default as estimated by Seller and Seller shall reimburse Buyer for all reasonable costs paid by Buyer in acquiring and delivering Substitute Supplies, including any demand charges or other sums due and owing to transporting pipelines during such period. over and above the incremental costs that would have been incurred by Buyer in acquiring and delivering natural gas purchased by Buyer from Seller under this Agreement (i.e., all costs Buyer has or would have paid to Seller or third parties other than any allocable portion of the lump-sum payment made by Buyer pursuant to Section 8.1) but not delivered due to Seller's default, with interest from the date of payment of such costs by Buyer until the date of reimbursement calculated at an annual rate equal to the Prime Interest Rate from time to time in effect plus one and twentyfive hundredths percent $(1.25 \%)$. If said period of default extends beyond the period initially estimated by Seller. Buyer may continue to obtain Substitute Supplies for the period that Buyer reasonably anticipates that Seller will remain in default and Seller shall reimburse Buyer for all reasonable costs paid by Buyer in acquiring and delivering Substitute Supplies, including any demand charges or other sums due and owing to transporting pipelines during such period, over and above the incremental costs that would have been incurred by Buyer in acquiring and delivering natural gas purchased by Buyer from Selter under this Agreement but not delivered due to Seller's default, with interest as aforesaid. Seller shall reimburse Buyer for the reasonable costs of Substitute Supplies, as defined herein, upon demand by Buyer at any time after such costs are actually incurred by Buyer and have been paid by Buyer or are due and payable to a third party.

(c) Buyer may elect to terminate this Agreement within five (5) Days after receipt of Seller's estimate of the anticipated duration of the period of default or at any time after expiration of the estimated period of default contained in Seller's notice. Buyer shall exercise its right to terminate by notifying Seller in writing of its intention to terminate. If Buyer elects to terminate this Agreement within five (5) Days after receipt of Seller's estimate, Seller shall have ninety (90) Days after receipt of Buyer's notice of intention to terminate in which to remove the cause of its default and indemnify Buyer as provided below. If Buyer elects to terminate this Agreement after expiration of the estimated period of default contained in Seller's notice, Seller shall have either ninety (90) Days after the commencement of Seller's default or thirty (30) Days after receipt of Buyer's notice of intention to terminate, whichever time period is longer, in which to remove the cause of its default and indemnify Buyer, as provided below. If, within the applicable time period, Seller does so remove or remedy said cause and fully indemnifies Buyer for

(i) all reasonable costs paid by Buyer in acquiring and delivering Substitute Supplies, including any demand charges or other sums due and owing to transporting pipelines during the duration of Seller's default, over and above the incremental costs that would have been incurred by Buyer in acquiring and delivering natural gas purchased by Buyer from Seller under this Agreement (i.c. all costs Buyer has or would have paid to Seller or third parties other than any allocable portion of the lump-sum payment made by Buyer pursuant to section 8.1) but not delivered to Buyer due to seller's default, with interest as calculated pursuant to subsection 12.1(b), or

(ii) if Buyer is unable to purchase and take delivery of Substitute Supplies at Buyer's Facilities, the fixed costs of Buyer's Facilities (including all payments Buyer is required to make to third parties not related to the profitability of Buyer's Facility and all income taxes 
attributable to the amount of the indemnity payments under this provision) that are paid or payable by Buyer to third parties as a consequence of seller's default. then the Agreement shall remain in full force and effect. Upon reimbursement by Seller to Buyer of such costs of Substitute Supplies, as required by the preceding clause (i), the quantities of natural gas acquired by Buyer as Substitute Supplies shall be added to the Consumed Amount.

(d) If Seller does not remedy and remove the cause of default and does not so indemnify Buyer within the applicable time period set forth in subsection 12.1 (c), then upon expiry of said period. this Agreement shall be terminated and be of no further force or effect. Upon termination. Seller shall pay to Buyer, in equal monthly installments (commencing fifteen (15) Days after the effective date of termination) over the one hundred and eighty (180) Days following the effective date of termination. the sum of

(i) the percentage of the lump-sum payment made by Buyer pursuant to Section 8.1 which is equal to the percentage derived by dividing the amount equal to the excess of the Maximum Entitlement over the Consumed Amount by the Maximum Entitlement:

(ii) interest from the period from the date of payment of the lump-sum payment to Seller to the effective date of termination on the amount so determined in subsection 12.1(d)(i). calculated based on quarterly compounding, at an annual rate equal to the Prime Interest Rate plus one and twenty-five hundredths percent $(1.25 \%)$ in effect from time to time during the periods from the date of payment of the lump-sum payment to Seller to the date of payment of such amounts;

(iii) the costs reasonably incurred by Buyer in acquiring and delivering Substitute Supplies to Buyer's Facilities, determined as set forth in subsection 12.1(c) (i). for the period from the date of seller's default until the effective date of termination: and

(iv) a lump-sum payout equal to the present value (based on a discount rate equal to the Prime Interest Rate plus one and twenty-five hundredths percent $(1.25 \%)$ as of the effective date of termination) of the excess, if any, of the aggregate costs that would be paid by Buyer. under the conditions existing on the effective date of termination. in acquiring and delivering Substitute Supplies equal in quantity to the Unconsumed Entitlement (to the extent Buyer would have been entitled pursuant to section 2.3 to obtain delivery of such quantity over the remaining term of the Agreement but for seller's default) over the sum of (x) the costs that Buyer would have paid for obtaining and delivery of such quantity if Seller had continued performance under this Agreement and $(y)$ the product of fifty-eight and thirty-three hundredths cents (\$.5833) per MMBtu and the Unconsumed Entitlement Seller may, within ninety (90) Days following the effective date of termination, arrange for a replacement contract from a source and on terms and conditions acceptable to Buyer acting reasonably for the sale and delivery to Buyer at the Point of Delivery of a quantity of natural gas equal to the Unconsumed Entitlement to the extent Buyer would have been entitled to obtain delivery of such quantity over the remaining term of the Agreement as of the effective date of termination (hereinafter the "Replacement Contract"). If Seller elects to arrange for such Replacement Contract, the amount payable by Buyer for Substitute Supplies in determining damages payable by Seller under this subsection 12.1 (d) (iv) shall be determined based on the costs established by such Replacement Contract. In determining damages payable by Seller pursuant to this subsection 12.1(d) (iv), Buyer's costs of oblaining delivery of Substitute Supplies shall include the purchase price of the required quantity of natural gas plus all production, gathering, processing and transportation costs, royalties and taxes payable in acquiring and delivering such quantities to Buyer's Facilities and the costs Buyer would have paid for obtaining delivery of such quantity under this Agreement shall include all production, gathering, processing and transportation costs, royalties and laxes that would have been payable by Buyer pursuant to this Agreement. Seller shall also remain responsible following termination of this Agreement pursuant to this section 12.I for the payment of any demand charges or other sums payable by Buyer to transporting pipelines under agreements for the transportation of natural gas sold by Seller to Buyer under this Agreement. Upon termination of this Agreement. Buyer shall take all reasonable steps to mitigate its damages.

(e) The costs of Substitute Supplies that are recoverable by Buyer from Seller pursuant to this section 12.1 shall not exceed the costs that were or would have been incurred in acquiring and delivering the lowest cost fuel which was at the time available to Buyer at Buyer's Facilities and of which Buyer could reasonably have been expected to have been aware. given the immediacy of Buyer's fuel consumption needs. Disputes between the Parties as to the reasonableness of the costs of acquiring and delivering Substitute Supplies shall be resolved pursuant to the arbitration provisions in Article 16, except that costs established by Replacement Contract acceptable to Buyer acting reasonably shall be conclusive and shall be deemedirreputably to be the lowest costs available for all periods after deliveries of natural gas are or would be (but for Buyer's inability or refusal to accept same) available to Buyer at the delivery point pursuant to the Replacement Contract. 
(f) This section 12.1 shall not be construed to limit the amount recoverable by Buyer from Seller in the event of termination following Seller's default or to relieve Seller from liability for payment of any amount due to Buyer pursuant to any other provision of this Agreement at the time of such termination.

The above provisions, in their thoroughness and length, are reflective of the exposure perceived by buyer to a default of seller's supply obligation. That exposure, of course, is largely a function of the substantial prepayment of the gas commodity costs. In the event of default, buyer has the right to secure substitute supplies and to request payment from seller of the incremental costs thereby incurred. Buyer may also discontinue payments for production, gathering and processing costs and for royalties and import and export taxes. Seller is obliged to give a reasonable estimate of the anticipated duration of the default and buyer has a right of termination, operative after a 90 day restorative period. If the contract is terminated, seller is obliged to repay a pro rata share of the prepaid commodity costs. Finally, to mitigate seller's exposure, seller has a right to arrange a replacement contract on terms and conditions reasonably acceptable to buyer.

While numerous other examples could be quoted, those that have been chosen are illustrative of the various alternatives commonly in use amongst buyers and sellers of gas. Let us know turn to a discussion of gas transportation.

\section{GAS TRANSMISSION}

Having now reviewed the provisions of gas purchase contracts pertaining to pricing, buyer's take obligation and seller's supply commitment, let us now turn to an examination of the gas transmission services presently offered by NOVA Corporation of Alberta and TransCanada PipeLines Limited. Unfortunately, space considerations do not permit a discussion of the transmission services offered by the various distribution companies operating in Canada.

\section{A. NOVA CORPORATION OF ALBERTA}

NOVA provides intra-Alberta and ex-Alberta services on a firm or interruptible basis.

\section{NOVA Intra-Alberta Gas Transmission Services}

NOVA provides three classes of intra-provincial gas transportation:

Rate Schedule T-1: Firm intra-provincial service providing transportation for a minimum of 12 months on a point-to-point basis in Alberta. Rates are volume based and vary according to the distance along the pipeline between the receipt and delivery station. There is an annual minimum charge which is based on $50 \%$ of the maximum volume contracted. A surcharge could be assessed in the event that significant incremental facilities are required.

Rate schedule T-2: Interruptible service is also volume/distance based. The term is for a minimum of three months and a maximum of one year and there is no minimum bill attached to this service. Facilities will not be installed for interruptible service.

Rate Schedule T-3: Service is available to any person removing gas from Alberta under a Gas Removal Permit to transport gas within Alberta to a designated delivery 
point in circumstances where the gas to be transported has been pre-empted and the point at which it was received on the NOVA system cannot be designated. Charges under Rate Schedule T-3 are volume related but not distance sensitive. There is no minimum charge for service under this Rate Schedule.

\section{NOVA Ex-Alberta Gas Transmission Services}

Rate Schedule T-5: Firm transportation service from a point within Alberta to a point of interconnection with an ex-Alberta pipeline. Short-term service is available for a minimum of one year and a maximum of two years where no new main line facilities are required. Long-term T- 5 service is available for a minimum of 15 years.

$\mathrm{T}-5$ transmission services are tolled on a demand/commodity basis. Rates are not distance sensitive but are tolled on a "postage stamp" basis. All fixed charges are assigned to the demand charge, based on maximum daily volumes contracted for at each of the receipt points and each of the delivery points. The commodity charge, which includes all variable costs, including fuel gas, is based on the monthly receipt volume into the pipeline system.

Rate Schedule T-6: T-6 is interruptible ex-Alberta service available for a minimum three month period. The monthly charge is based on a commodity rate multiplied by the actual monthly receipt volumes and there is no minimum bill or demand charge. Facilities will not be installed for interruptible service.

\section{Charges For NOVA Transportation Service}

Appendix " $A$ " sets forth the gas transmission charges in effect to October 31, 1988 for the various classes of NOVA gas transmission services.

\section{Changes Expected In NOVA Gas Transmission Tariff}

Section 22 of the NOVA Corporation of Alberta Act" provides that the Gas Utilities Act does not apply to the NOVA Corporation or its operations except with respect to gas purchased or owned by the Corporation.

Section 37 of the NOVA Act ${ }^{12}$ provides, inter alia, that the Corporation may fix and vary, from time to time, the various rates, tolls and charges for the gas transmission services provided by it. The Public Utilities Board of Alberta ("PUB") may, on receiving written complaint by an interested party, determine the justness and reasonableness of the rates, tolls and other charges fixed or varied by the NOVA Corporation and by order in writing, may vary or confirm same.

Should the PUB vary a rate, toll or other charge, the variation shall remain in effect no longer than 12 months. Finally, Part 1 of the Public Utilities Board Act of Alberta ${ }^{13}$ applies with respect to the foregoing jurisdiction of the PUB insofar as there is no conflict with section 37 of the NOVA Act.

Section 40 of the NOVA Act ${ }^{14}$ bestows jurisdiction on the Energy Resources Conservation Board to review decisions made by NOVA respecting terms and

11. NOVA, An Alberta Corporation Act, R.S.A. 1980, c. N-12, as am., s. 22.

12. Id. at s. 37 .

13. Public Utilities Board Act, R.S.A. 1980, c. P-37, as am.

14. Supra n. 12 s. 40. 
conditions of service. The ERCB may, after conducting a hearing, confirm or vary the decision.

NOVA is unique amongst gas transmission companies in Canada to the extent it is permitted self-regulation.

The only reported decision under sections 37 and 40 of the NOVA Act is Alberta Gas Trunk Line Company v. Amoco Canada Petroleum Company ${ }^{15}$ which, among other things, decided that the rates, tolls and other charges mentioned in section 37(1) are not diminished but rather, are illustrated and amplified by the reference following those words to "rates and other methods of depreciation and amortization, determination of rate base and rate of return thereof".

The lack of cases cited under sections 37 and 40 of the NOVA Act is perhaps representative as much of the reasonableness of NOVA in dealing with its shippers as it is of the relatively few shippers with whom it has dealt. As of late, the number of shippers with whom NOVA interacts has greatly increased as has the competitiveness amongst those shippers for market advantages. NOVA may find itself unable to achieve consensus as readily as in the past and may find that more frequent referrals to the PUB and ERCB are forthcoming.

In April, 1988, NOVA circulated a discussion paper on pipeline access for firm transportation service. The purpose of the paper was to address the issue of access to firm transportation service at existing receipt points on the NOVA system. In that paper, NOVA posed five alternatives and solicited written comments from the industry, to be received by May 31, 1988.

It is widely anticipated that changes will also be proposed by NOVA to the provisions pertaining to each of the intra-Alberta rate schedules. Specifically, NOVA may adopt rates for T-1 and T-2 which are of a "postage stamp" nature, not sensitive to distance. T-1 may be tolled on a commodity or demand/commodity basis. NOVA presently has a moratorium on granting additional T-3 delivery points other than where the delivery is of make-up gas to a straddle plant.

\section{B. TRANSCANADA PIPELINES LIMITED TRANSPORTATION SERVICES}

TCPL offers transportation services on either a short-term or long-term basis through each of the five zones it operates.

\section{Long-Term Transportation Services}

Long-term transportation services are available to any shipper pursuant to subsection 59(2) of the National Energy Board Act ${ }^{16}$ and to every other shipper meeting the conditions of availability set forth in the TCPL tariff. The minimum term is 15 years. Tolling is on a demand/commodity basis and the minimum monthly bill is the applicable demand charge. Both demand and commodity charges vary according to the toll zone in which the delivery point is located. Demand tolls also vary in accordance with the capacity reserved on the TCPL system and commodity tolls vary in accordance with the volumes actually shipped.

15. Alberia Gas Trunk Line Company Lid. v. Amoco Canada Petroleum Company Lid. [1980] 3 W.W.R. 1, (1980) 20 A.R. 384 (Alta. C.A.), affd. [1981] 6 W.W.R. 391, (1981) 32 A.R. 613, there cited as Nova v. Amoco Canada Petroleum Company Lid.

16. National Energy Board Act, R.S.C. 1970, c. N-6, s. 23. 


\section{Short-Term Transportation Services}

Short-term T-services are available from TCPL for a minimum term of one year and a maximum term of three years. Additional facilities will not be constructed for short-term T-service. The TCPL toll schedule for short-term T-service presently contains, in section 2.8 , provisions permitting TCPL to "bump" a short-term shipper in favour of various other classes of service on the terms and conditions set forth therein.

The tolls applicable to short-term transportation service are structured on a demand and commodity basis according to the toll zone in which the delivery point is located. The minimum bill is the applicable demand charge. It is noteworthy that (notwithstanding the "bumping" provisions referred to above) the transportation tolls for short-term transportation service are identical in both their amount and calculation as those for long-term transportation service.

\section{Charges For TCPL Transportation Services}

Appendix "B" sets out the gas transmission charges in effect to October 31, 1988 for the classes of TCPL gas transmission services addressed herein.

\section{Changes Expected in TCPL Gas Transmission Tariff}

At the time of writing this paper, the National Energy Board was convening the TransCanada 1988/89 toll hearing under Hearing Order No. RH-1-88. Issues expected to be addressed at the hearing, briefly summarized, include the following:

- displacement issues including the operating demand (OD) methodology in order to examine the proper adjustments to be included in TCPL's approved rates to reflect the loss of "system" sales to "direct" sales,

- fuel gas: procedures regarding supply of fuel by shippers,

- umbrella T-service, whereby TCPL is required to maintain unused capacity to be available for transportation service for direct sales customers,

- incremental versus rolled-in tariffs, to decide the method to be used by TCPL in its tariff in circumstances where a customer requires expansion of the TCPL system, the issue here being whether the shipper specifically should pay the costs of such expansion or whether the costs should be borne by all shippers.

\section{GAS REMOVAL PERMITS}

The Gas Resources Preservation Act of Alberta ${ }^{17}$ ("GRPA") confers jurisdiction on the Energy Resources Conversation Board of Alberta in respect of gas removal permits. Section 2(1) of the GRPA provides as follows:

2(1) Application for Permit. When a person

(a) produces or has the right to produce gas or propane in Alberta.

(b) appears to the Board, on evidence that the Board in its sole discretion considers sufficient,

to have made an arrangement

(i) to purchase or otherwise acquire property in gas or propane in Alberta. or

(ii) giving him the exclusive right to dispose of that gas or propane.

17. Gas Resources Preservation Act, S.A. 1984, c. G-3.1. as am. 
or

(c) appears to the Board, on evidence that the Board in its sole discretion considers sufficient, to have made an arrangement with the owner of gas or propane produced in Alberta to transport that gas or propane to a place outside Alberta.

and proposes to remove gas or propane, or cause it to be removed, from Alberta, that person may apply to the Board for a permit authorizing the removal from Alberta of gas or propane, of which the gas or propane referred to in clause (a), (b), or (c) will be, in the opinion of the Board, the substantial part.

There are three types of permits which may be issued

- long-term permit for removal of volumes greater than three billion cubic metres or requiring a permit term longer than two years (in which case the permit will issue only with the approval of the Lieutenant-Governor in Council),

- short-term small-volume permit for volumes not exceeding three billion cubic metres and a permit term not exceeding two years (in which case Ministerial Approval from the Minister of Energy is required before the permit will issue), and

- spot sales permit for removal of volumes of less than one billion cubic meters and for a term not exceeding four months (in which case Ministerial Approval will be required from the Minister of Energy before the permit will issue).

Legislative authority for the above is found in sections 4 and 6 of the Gas Resources Preservation Act.

Section 8 of the Gas Resources Preservation Act provides that the Board may not grant a permit unless, in its opinion, to do so is in the public interest of Alberta. ERCB Informational Letter IL-87 (draft) sets forth the criteria upon which it will assess removal permit applications:

- are reserves available for export from Alberta having regard to the most recent calculations respecting supply of and requirements for Alberta gas?

- does the applicant own or has it made arrangements to acquire sufficient reserves to satisfy the applied-for permit?

- have suitable transportation arrangements been made?

- are major new facilities required and, if so, are they economically viable?

- what marketing arrangements are in place and are they in the Alberta public interest?

The Alberta Permit Conditions Regulation ${ }^{18}$ was enacted pursuant to the Gas Resources Preservation Act. This Regulation applies to all Gas Removal Permits granted before or after the Regulation came into force. Among other things, the Regulation requires that an applicant for permit shall file with the Minister adequate information respecting existing or proposed downstream arrangements and that every permit be subject to the condition that the permittee will file information requested in writing by the Minister relating to gas removed or to be removed from Alberta pursuant to the permit.

Considerable controversy has arisen recently as to the Government's refusal to approve permits where the price of gas proposed to be removed was below a minimum price acceptable to the Government. It has been repeatedly speculated that the Government's rationale was firstly, to maximize its royalties and secondly, to use

18. Permit Conditions Regulation, Alta. Reg. 271/87, as am. 370/87, 380/87. 
the removal permit process as a means to facilitate the adoption in the consuming provinces of core market supply criteria. This political issue remains unresolved as of the date of writing this paper.

Finally, there are additional conditions imposed by the Permit Conditions Regulation including the provisions of section 6 therein which prohibit self-displacement gas being sold to a distributor.

Pursuant to a joint inquiry conducted by the ERCB and the PUB, recommendations were given to the Government as to the procedures to be used to secure a source of supply of natural gas for the core market in Alberta. As of the date of writing this paper, the Government had not taken any legislative action on those recommendations.

\section{CONCLUSION}

This paper, in taking a practical approach to natural gas marketing, has attempted to assist counsel in analyzing proposed gas purchase contracts having particular regard to the provisions which pertain to pricing, buyer's take obligations and seller's supply commitment. The various examples which have been offered are representative only of various alternative provisions which are circulating within the industry and are not to be considered exhaustive of the variety of clauses counsel may wish to consider.

We have seen the difficulty in attempting to negotiate long-term gas purchase contract provisions which will survive all changes, predictable and otherwise. Counsel were cautioned to use tools such as arbitration carefully by incorporating clear statements of intent in order to permit the arbitrators to accurately adjust the contract.

While at this time the pace of legislative and regulatory change may well be slackening, the pace of consequential change in how buyers and sellers contract for the purchase of gas and for its transportation continues to grow. That process must further evolve before the present restructuring of the natural gas industry will be complete. 


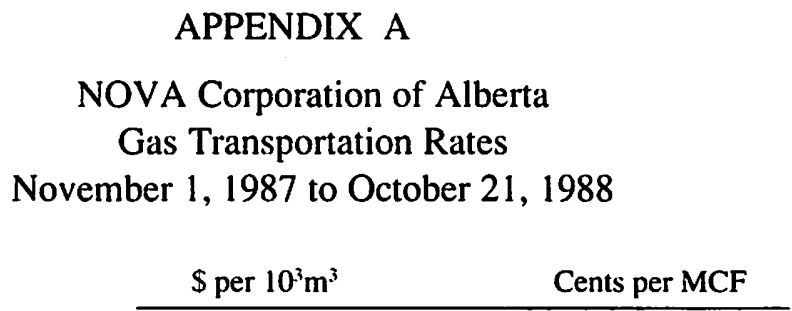

INTRA-PROVINCIAL

T-I Firm Service

MaximumRrate:

T-2 Interruptible

Maximum Rate

\section{EX-ALBERTA}

T-5 Firm Service

Demand Rate

Commodity Rate

T-6 Interruptible
$\$ 0.022 / 10^{3} \mathrm{~m}^{3} / \mathrm{km}$

$\$ 8.50 / 10^{3} \mathrm{~m}^{3}$

$\$ 0.022 / 10^{3} \mathrm{~m}^{3} / \mathrm{km}$

$\$ 6.50 / 10^{3} \mathrm{~m}^{3}$
10 cents/MCF/100 miles 24 cents/MCF

10 cents $/ \mathrm{MCF} / 100$ miles 18.3 cents/MCF
$\$ 66.50 / 10^{3} \mathrm{~m}^{3} /$ month of daily $\mathrm{CDQ}^{1}$

$\$ 0.25 / 10^{3} \mathrm{~m}^{3}$

$\$ 6.50 / 10^{3} \mathrm{~m}^{3}$
\$1.87/MCF/month of daily $C D Q$

0.7 cents/MCF

18.3 cents/MCF

1. CDQ or Contract Demand Quantity is the sum of receipt and delivery maximum daily volumes. 
APPENDIX B

TRANSCANADA PIPELINES LIMITED

T TOLL SCHEDULES

Transportation

\begin{tabular}{lccc}
$\begin{array}{c}\text { Applicable Toll } \\
\text { Schedule and } \\
\text { Toll Zone }\end{array}$ & $\begin{array}{c}\text { Commodity } \\
\text { Toll } \\
\$ / 10^{3} \mathrm{~m}^{3}\end{array}$ & $\begin{array}{c}\text { Monthly } \\
\text { Demand } \\
\text { Toll } \\
\$ / 10^{3} \mathrm{~m}^{3}\end{array}$ & $\begin{array}{c}\text { Daily } \\
\text { Demand } \\
\text { Toll } \\
\$ / 10^{3} \mathrm{~m}^{3}\end{array}$ \\
\hline T-S Saskatchewan & 0.982 & 180.85 & 5.946 \\
T-M Manitoba & 2.127 & 315.35 & 10.368 \\
T-W Westem & 3.917 & 519.86 & 17.091 \\
T-N Northern & 6.339 & 807.91 & 26.561 \\
T-E Eastern & 7.978 & 1001.20 & 32.916
\end{tabular}

